\title{
Durumolides A-E, anti-inflammatory and antibacterial cembranolides from the soft coral Lobophytum durum
}

\author{
Shi-Yie Cheng ${ }^{a}$, Zhi-Hong Wen ${ }^{a}$, Shu-Fen Chiou ${ }^{a}$, Chi-Hsin Hsu ${ }^{\text {a,e }}$, Shang-Kewi Wang ${ }^{b}$, \\ Chang-Feng Dai ${ }^{c}$, Michael Y. Chiang ${ }^{\mathrm{d}}$, Chang-Yih Duh ${ }^{\mathrm{a}, \mathrm{e}, *}$ \\ a Department of Marine Biotechnology and Resources, National Sun Yat-Sen University, Kaohsiung 804, Taiwan \\ ${ }^{\mathrm{b}}$ Department of Microbiology, Kaohsiung Medical University, Kaohsiung 807, Taiwan \\ ${ }^{c}$ Institute of Oceanography, National Taiwan University, Taipei, Taiwan \\ d Department of Chemistry, National Sun Yat-sen University, Kaohsiung 804, Taiwan \\ ${ }^{\mathrm{e}}$ Center of Asia-Pacific Marine Researches, National Sun Yat-sen University, Kaohsiung, Taiwan
}

\section{A R T I C L E I N F O}

\section{Article history:}

Received 19 June 2008

Received in revised form 25 July 2008

Accepted 25 July 2008

Available online 30 July 2008

\section{Keywords:}

Lobophytum durum

Cembranoid

$\alpha$-Methylene- $\gamma$-lactone

Anti-inflammatory effects

Antibacterial activities

HCMV endonuclease activity

\begin{abstract}
A B S T R A C T
Chemical investigations on the acetone extract of the soft coral Lobophytum durum have afforded five new cembranoids with a trans-fused $\alpha$-methylene- $\gamma$-lactone, durumolides A-E (1, 6, and 8-10), and five previously characterized cembrane-based diterpenoids (2-5 and 7). The structures of the isolated metabolites were elucidated through extensive spectroscopic analyses, while the relative stereochemistry of $\mathbf{4}$ was confirmed by X-ray diffraction analyses. Moreover, the absolute configurations of 3-5 and 8 were established by application of modified Mosher's method. The anti-inflammatory effects, antibacterial activities, and inhibition assay of HCMV (Human cytomegalovirus) endonuclease activity of these isolated metabolites 1-10 were evaluated in vitro.
\end{abstract}

(c) 2008 Elsevier Ltd. All rights reserved.

\section{Introduction}

Soft corals belonging to the genus Lobophytum (Alcyoniidae) have proven to be a rich source of macrocyclic cembrane-type diterpenes and their cyclized derivatives. ${ }^{1-16}$ Some of these metabolites have been shown to exhibit cytotoxic properties. ${ }^{2-6}$ The ongoing search for bioactive constituents prompted us to investigate the secondary metabolites of the soft coral Lobophytum durum (Tixier-Durivault, 1956), chemical constituents and bioactivity of which were not reported previously. We have succeeded in the isolation of five new cembranoids possessing a $\alpha$-methylene$\gamma$-lactone ring trans-fused to a 14-membered ring, durumolides A-E $(\mathbf{1}, \mathbf{6}$, and 8-10), and five previously characterized $\alpha$-methylene- $\gamma$-lactone-bearing cembranolides (2-5 and 7) ${ }^{10-13,17}$ from the acetone extract of the organism. In the article, we report the structural elucidation, anti-inflammatory effects, antibacterial activities, and inhibition assay of HCMV endonuclease activity of these metabolites.

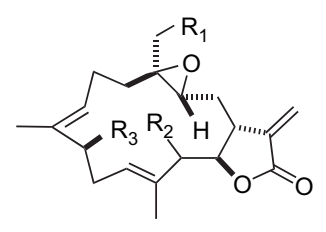

$1 \mathrm{R}_{1}=\mathrm{OAC} \quad \mathrm{R}_{2}=(R)-\mathrm{OH} \quad \mathrm{R}_{3}=\mathrm{OH}$

$2 \mathrm{R}_{1}=\mathrm{OAC} \quad \mathrm{R}_{2}=(S)-\mathrm{OH} \quad \mathrm{R}_{3}=\mathrm{H}$

$3 \mathrm{R}_{1}=\mathrm{OAc} \quad \mathrm{R}_{2}=(R)-\mathrm{OH} \quad \mathrm{R}_{3}=\mathrm{H}$

$4 \mathrm{R}_{1}=\mathrm{OH} \quad \mathrm{R}_{2}=(R)-\mathrm{OH} \quad \mathrm{R}_{3}=\mathrm{H}$

$5 \mathrm{R}_{1}=\mathrm{OH} \quad \mathrm{R}_{2}=(S)-\mathrm{OH} \quad \mathrm{R}_{3}=\mathrm{H}$
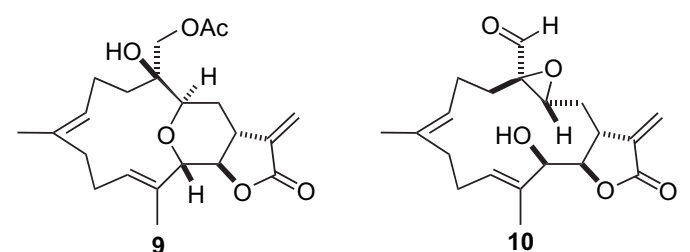

\section{Results and discussion}

\footnotetext{
* Corresponding author. Tel.: +886 7 5252000x5036; fax: +886 75255020 .

E-mail address: yihduh@mail.nsysu.edu.tw (C.-Y. Duh).
}

The acetone extract of $L$. durum was partitioned between EtOAc and $\mathrm{H}_{2} \mathrm{O}$ to afford the EtOAc-soluble fraction, which was then 
subjected to column chromatography on silica gel. The fractions containing terpenoids were selected after the ${ }^{1} \mathrm{H}$ NMR spectrum revealed the presence of various terpenoids, and these fractions were further purified by a series of normal and reversed-phase HPLC to afford 1-10 (see Section 3).

Compound $\mathbf{4}$ has been previously isolated from the soft coral Lobophytum crassum. ${ }^{12}$ Definitive support for the proposed structure of $\mathbf{4}$ was provided by X-ray crystallographic analysis of colorless crystals (Fig. 1). The appropriate stereochemistry of $\mathbf{4}$ was determined by spectroscopic method according to Mosher's acylation for absolute configuration determination of chiral alcohols. ${ }^{18}$ Analysis of the $\Delta \delta_{S-R}$ values (Fig. 2) according to the Mosher model pointed to an $R$ configuration for $\mathrm{C}-13$ of 4 , because $\mathrm{H}_{2}-9, \mathrm{H}_{2}-10, \mathrm{H}-$ 11, Me-19, and Me-20 of (S)-MTPA ester 4a were less shielded by the phenyl ring of MTPA products. Therefore, the absolute stereochemistry of $\mathbf{4}$ was established unambiguously.

Durumolide A (1), appeared as a colorless oil, was isolated as the most polar metabolite. Its HRESIMS $\left(\mathrm{m} / z\right.$ 429.1890, $\left.[\mathrm{M}+\mathrm{Na}]^{+}\right)$and NMR spectroscopic data (Tables 1 and 2) established the molecular formula $\mathrm{C}_{22} \mathrm{H}_{30} \mathrm{O}_{7}$, implying the existence of eight degrees of unsaturation. The IR absorptions of 1 at 1765 and $1663 \mathrm{~cm}^{-1}$ revealed the presence of an $\alpha$-methylene- $\gamma$-lactone moiety. This was further indicated from the ${ }^{1} \mathrm{H}$ NMR signals at $\delta 6.32(1 \mathrm{H}, \mathrm{d}$,

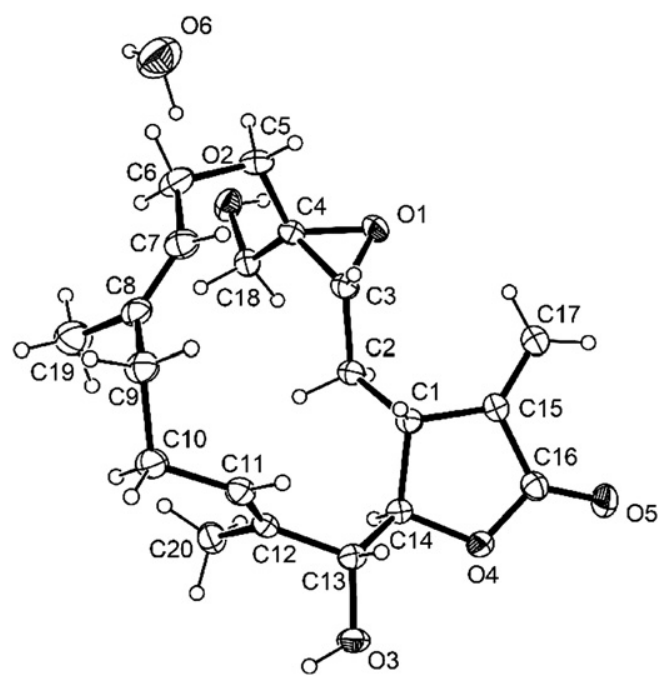

Figure 1. X-ray ORTEP diagram of 4.

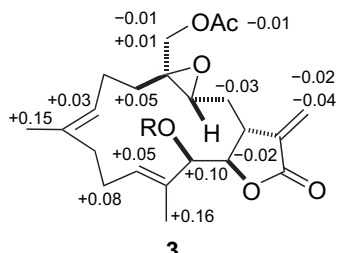

3

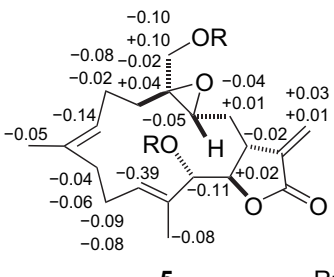

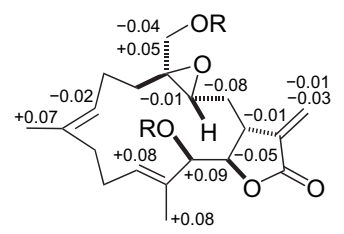

4

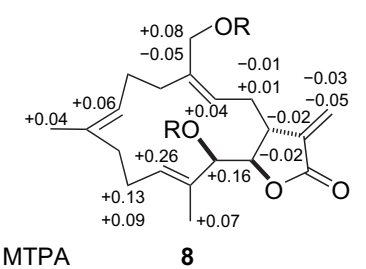

Figure 2. Selected ${ }^{1} \mathrm{H}$ NMR $\Delta \delta_{S-R}$ values in parts per million for the $S$ - and $R$-MTPA esters of 3-5 and $\mathbf{8}$ in $\mathrm{CDCl}_{3}$.
Table 1

${ }^{1}$ H NMR spectral data of compounds $\mathbf{1}$ and $\mathbf{6}$

\begin{tabular}{|c|c|c|}
\hline $\mathrm{H} \#$ & $\mathbf{1}^{\mathrm{a}}$ & $6^{\mathrm{a}}$ \\
\hline 1 & $2.78 \mathrm{~m}$ & $2.73 \mathrm{~m}$ \\
\hline 2 & a: $1.87 \mathrm{br} \mathrm{d}(14.1)^{\mathrm{b}} ; \mathrm{b}: 1.50 \mathrm{~m}$ & $\mathrm{a}: 2.38 \mathrm{~m} ; \mathrm{b}: 2.34 \mathrm{~m}$ \\
\hline 3 & $2.78 \mathrm{~m}$ & $5.27 \mathrm{t}(7.6)^{\mathrm{b}}$ \\
\hline 5 & a: $2.46 \mathrm{~m} ; \mathrm{b}: 1.18 \mathrm{td}(12.3,2.6)$ & $\mathrm{a}: 2.32 \mathrm{~m} ; \mathrm{b}: 2.25 \mathrm{~m}$ \\
\hline 6 & a: $2.39 \mathrm{~m} ; \mathrm{b}: 2.16 \mathrm{~m}$ & a: $2.27 \mathrm{~m} ; \mathrm{b}: 2.22 \mathrm{~m}$ \\
\hline 7 & 5.36 br d $(6.0)$ & 4.89 br t $(7.5)$ \\
\hline 9 & 4.11 dd $(14.3,2.0)$ & a: $2.15 \mathrm{~m} ; \mathrm{b}: 2.10 \mathrm{~m}$ \\
\hline 10 & a: $2.78 \mathrm{~m} ; \mathrm{b}: 2.35 \mathrm{~m}$ & a: $2.36 \mathrm{~m} ; \mathrm{b}: 2.19 \mathrm{~m}$ \\
\hline 11 & $5.47 \mathrm{br} \mathrm{d}(5.7)$ & 5.36 br dd $(8.4,4.7)$ \\
\hline 13 & $4.08 \mathrm{br} \mathrm{s}$ & $3.75 \mathrm{~d}(8.0)$ \\
\hline 14 & 4.08 br s & $4.22 \mathrm{dd}(8.0,2.3)$ \\
\hline 17 & a: $6.32 \mathrm{~d}(2.7) ; \mathrm{b}: 6.05 \mathrm{~d}(2.2)$ & a: $6.32 \mathrm{~d}(1.9) ;$ b: $5.73 \mathrm{~d}(1.5)$ \\
\hline 18 & a: $4.43 \mathrm{~d}$ (12.4); b: $3.84 \mathrm{~d}(12.4)$ & $4.55 \mathrm{~s}$ \\
\hline 19 & $1.71 \mathrm{~s}$ & $1.62 \mathrm{~s}$ \\
\hline 20 & $1.74 \mathrm{~s}$ & $1.72 \mathrm{~s}$ \\
\hline OAc & $2.14 \mathrm{~s}$ & $2.07 \mathrm{~s}$ \\
\hline
\end{tabular}

a Spectra were measured in $\mathrm{CDCl}_{3}(300 \mathrm{MHz})$

b $\mathrm{J}$ values (in $\mathrm{Hz}$ ) are in parentheses.

Table 2

${ }^{13} \mathrm{C}$ NMR spectral data of compounds $\mathbf{1}, \mathbf{6}$, and 8-10

\begin{tabular}{|c|c|c|c|c|c|}
\hline C\# & $1^{a}$ & $6^{\mathrm{a}}$ & $8^{a}$ & $9^{a}$ & $10^{\mathrm{b}}$ \\
\hline 1 & $42.1(\mathrm{CH})^{\mathrm{C}}$ & $42.0(\mathrm{CH})^{\mathrm{C}}$ & $42.2(\mathrm{CH})^{\mathrm{C}}$ & $38.8(\mathrm{CH})^{\mathrm{C}}$ & $42.8(\mathrm{CH})^{\mathrm{C}}$ \\
\hline 2 & $31.1\left(\mathrm{CH}_{2}\right)$ & $34.1\left(\mathrm{CH}_{2}\right)$ & $33.8\left(\mathrm{CH}_{2}\right)$ & $36.1\left(\mathrm{CH}_{2}\right)$ & $31.2\left(\mathrm{CH}_{2}\right)$ \\
\hline 3 & $62.5(\mathrm{CH})$ & $126.6(\mathrm{CH})$ & $124.5(\mathrm{CH})$ & $71.0(\mathrm{CH})$ & $63.9(\mathrm{CH})$ \\
\hline 4 & $60.3(\mathrm{qC})$ & $135.8(\mathrm{qC})$ & $140.3(\mathrm{qC})$ & $75.4(\mathrm{qC})$ & $64.5(\mathrm{qC})$ \\
\hline 5 & $32.5\left(\mathrm{CH}_{2}\right)$ & $34.6\left(\mathrm{CH}_{2}\right)$ & $34.6\left(\mathrm{CH}_{2}\right)$ & $34.1\left(\mathrm{CH}_{2}\right)$ & $30.1\left(\mathrm{CH}_{2}\right)$ \\
\hline 6 & $24.1\left(\mathrm{CH}_{2}\right)$ & $24.3\left(\mathrm{CH}_{2}\right)$ & $24.2\left(\mathrm{CH}_{2}\right)$ & $22.0\left(\mathrm{CH}_{2}\right)$ & $24.1\left(\mathrm{CH}_{2}\right)$ \\
\hline 7 & $129.0(\mathrm{CH})$ & $123.5(\mathrm{CH})$ & $123.7(\mathrm{CH})$ & $124.3(\mathrm{CH})$ & $124.3(\mathrm{CH})$ \\
\hline 8 & $137.8(\mathrm{qC})$ & $133.9(\mathrm{qC})$ & $133.9(\mathrm{qC})$ & $136.3(\mathrm{qC})$ & $136.2(\mathrm{qC})$ \\
\hline 9 & $77.9(\mathrm{CH})$ & $37.5\left(\mathrm{CH}_{2}\right)$ & $37.6\left(\mathrm{CH}_{2}\right)$ & $37.5\left(\mathrm{CH}_{2}\right)$ & $38.5\left(\mathrm{CH}_{2}\right)$ \\
\hline 10 & $33.2\left(\mathrm{CH}_{2}\right)$ & $24.4\left(\mathrm{CH}_{2}\right)$ & $24.4\left(\mathrm{CH}_{2}\right)$ & $24.9\left(\mathrm{CH}_{2}\right)$ & $25.2\left(\mathrm{CH}_{2}\right)$ \\
\hline 11 & $126.8(\mathrm{CH})$ & $131.3(\mathrm{CH})$ & $131.0(\mathrm{CH})$ & $131.1(\mathrm{CH})$ & $132.5(\mathrm{CH})$ \\
\hline 12 & $133.5(\mathrm{qC})$ & $131.9(\mathrm{qC})$ & $132.1(\mathrm{qC})$ & $132.9(\mathrm{qC})$ & $132.1(\mathrm{qC})$ \\
\hline 13 & $80.8(\mathrm{CH})$ & $79.1(\mathrm{CH})$ & $78.9(\mathrm{CH})$ & $79.5(\mathrm{CH})$ & $81.4(\mathrm{CH})$ \\
\hline 14 & $81.8(\mathrm{CH})$ & $83.7(\mathrm{CH})$ & $83.8(\mathrm{CH})$ & $84.6(\mathrm{CH})$ & $82.1(\mathrm{CH})$ \\
\hline 15 & $138.3(\mathrm{qC})$ & $138.4(\mathrm{qC})$ & $138.6(\mathrm{qC})$ & $138.9(\mathrm{qC})$ & $138.5(\mathrm{qC})$ \\
\hline 16 & $168.8(\mathrm{qC})$ & $169.6(\mathrm{qC})$ & $169.8(\mathrm{qC})$ & $169.7(\mathrm{qC})$ & $168.9(\mathrm{qC})$ \\
\hline 17 & $124.5\left(\mathrm{CH}_{2}\right)$ & $123.3\left(\mathrm{CH}_{2}\right)$ & $123.2\left(\mathrm{CH}_{2}\right)$ & $124.3\left(\mathrm{CH}_{2}\right)$ & $124.7\left(\mathrm{CH}_{2}\right)$ \\
\hline 18 & $63.6\left(\mathrm{CH}_{2}\right)$ & $61.6\left(\mathrm{CH}_{2}\right)$ & $60.0\left(\mathrm{CH}_{2}\right)$ & $67.6\left(\mathrm{CH}_{2}\right)$ & $199.3(\mathrm{CH})$ \\
\hline 19 & $11.1\left(\mathrm{CH}_{3}\right)$ & $17.0\left(\mathrm{CH}_{3}\right)$ & $16.9\left(\mathrm{CH}_{3}\right)$ & $17.2\left(\mathrm{CH}_{3}\right)$ & $15.8\left(\mathrm{CH}_{3}\right)$ \\
\hline 20 & $12.5\left(\mathrm{CH}_{3}\right)$ & $13.2\left(\mathrm{CH}_{3}\right)$ & $13.3\left(\mathrm{CH}_{3}\right)$ & $14.3\left(\mathrm{CH}_{3}\right)$ & $12.5\left(\mathrm{CH}_{3}\right)$ \\
\hline \multirow[t]{2}{*}{ OAC } & $20.8\left(\mathrm{CH}_{3}\right)$ & $20.9\left(\mathrm{CH}_{3}\right)$ & & $20.9\left(\mathrm{CH}_{3}\right)$ & \\
\hline & $170.8(\mathrm{qC})$ & $170.9(\mathrm{qC})$ & & $171.6(\mathrm{qC})$ & \\
\hline
\end{tabular}

a Spectra were measured in $\mathrm{CDCl}_{3}(75 \mathrm{MHz})$

b Spectra were measured in $\mathrm{CDCl}_{3}(100 \mathrm{MHz})$.

c Multiplicities are deduced by HSQC and DEPT experiments.

$J=2.7 \mathrm{~Hz})$ and $6.05(1 \mathrm{H}, \mathrm{d}, J=2.2 \mathrm{~Hz})$ and ${ }^{13} \mathrm{C}$ NMR signals at $\delta 168.8$ (qC, C-16), 138.3 (qC, C-15), 124.5 ( $\left.\mathrm{CH}_{2}, \mathrm{C}-17\right), 81.8$ (CH, C-14), and 42.1 ( $\mathrm{CH}, \mathrm{C}-1)$. A strong IR spectrum absorption at $1745 \mathrm{~cm}^{-1}$ indicated the presence of an acetoxy group. Two secondary hydroxyls were recognized as being present in $\mathbf{1}$ from its ${ }^{1} \mathrm{H}$ NMR signals at $\delta 4.11(1 \mathrm{H}, \mathrm{dd}, J=14.3,2.0 \mathrm{~Hz})$ and $4.08(1 \mathrm{H}, \mathrm{br} \mathrm{s})$ and ${ }^{13} \mathrm{C}$ NMR signals at $\delta 77.9(\mathrm{CH}, \mathrm{C}-9)$ and $80.8(\mathrm{CH}, \mathrm{C}-13)$, as well as from a broad IR absorption at $3458 \mathrm{~cm}^{-1}$. Moreover, the ${ }^{13} \mathrm{C}$ NMR signals at $\delta 137.8$ (qC, C-8), 133.5 (qC, C-12), $129.0(\mathrm{CH}, \mathrm{C}-7), 126.8(\mathrm{CH}$, $\mathrm{C}-11), 62.5(\mathrm{CH}, \mathrm{C}-3)$, and 60.3 (qC, C-4) assigned two trisubstituted double bonds and one trisubstituted epoxide in $\mathbf{1}$, respectively. The above functionalities also account for six of the eight degrees of unsaturation, suggesting a bicyclic structure in $\mathbf{1}$. By interpretation of ${ }^{1} \mathrm{H}-{ }^{1} \mathrm{H}$ COSY correlations, it was possible to establish three partial structures of consecutive proton systems extending from $\mathrm{H}-3$ to $\mathrm{H}_{2}-13$ through $\mathrm{H}_{2}-2, \mathrm{H}-1$, and $\mathrm{H}-14$, from $\mathrm{H}_{2}-5$ to $\mathrm{H}-7$, and from $\mathrm{H}-9$ to $\mathrm{H}-11$, as well as long-range COSY correlations between $\mathrm{H}-1$ / $\mathrm{H}_{2}-17, \mathrm{H}_{3}-19 / \mathrm{H}-7$, and $\mathrm{H}_{3}-20 / \mathrm{H}-11$. Moreover, the connectivities of these partial structures were further established by the HMBC correlations (Fig. 3). The long-range ${ }^{1} \mathrm{H}-{ }^{13} \mathrm{C}$ correlations observed 

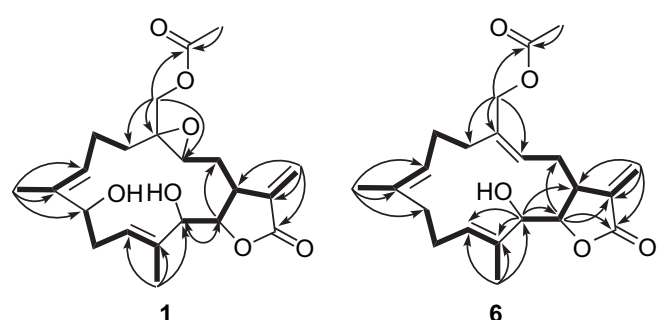

6
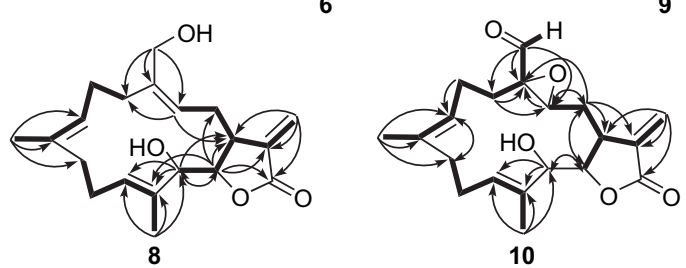

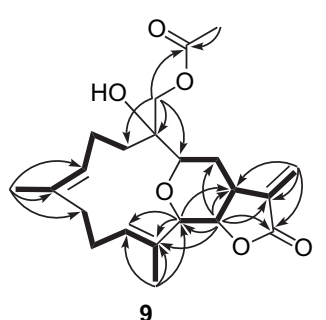

Figure 3. ${ }^{1} \mathrm{H}-{ }^{1} \mathrm{H} \operatorname{COSY}(\longrightarrow)$ and key $\operatorname{HMBC}(\rightarrow)$ correlations of $\mathbf{1}, \mathbf{6}$, and 8-10.

from $\mathrm{H}_{2}-18$ to $\mathrm{C}-3, \mathrm{C}-4, \mathrm{C}-5$, and the carbonyl carbon of $18-\mathrm{OAC}$ indicated the position of the epoxide at $\mathrm{C}-3$ and $\mathrm{C}-4$. In addition, the HMBC correlations from $\mathrm{H}_{3}-19$ to $\mathrm{C}-7, \mathrm{C}-8$, and $\mathrm{C}-9$ and from $\mathrm{H}_{3}-20$ to $\mathrm{C}-11, \mathrm{C}-12$, and $\mathrm{C}-13$ led the assignment of the two secondary hydroxyls at $\mathrm{C}-9$ and $\mathrm{C}-13$. The locations of the two double bonds at C-7/C-8 and C-11/C-12 were clarified by analysis of the above HMBC correlations. Thus, the gross structure of durumolide A was assigned as $\mathbf{1}$, possessing an $\alpha$-methylene- $\gamma$-lactone ring fused to a 14-membered ring at C-1 and C-14. A computer-modeled 3D structure (Fig. 4) of 1 was generated by using MM2 force field calculations for energy minimization with the molecular modeling program Chem 3D Ultra 9.0. The relative stereochemistry of $\mathbf{1}$ assigned by NOESY spectrum was compatible with those of $\mathbf{1}$ offered by computer modeling, in which the close contacts of atoms calculated in space were consistent with the NOESY correlations. The NOE correlations (Fig. 4) between $\mathrm{H}-1 / \mathrm{H}-3, \mathrm{H}-1 / \mathrm{H}-11, \mathrm{H}-1 / \mathrm{H}-$ $13, \mathrm{H}-11 / \mathrm{H}-13, \mathrm{H}-11 / \mathrm{H}-9, \mathrm{H}-3 / \mathrm{H}-5 \mathrm{~b}(\delta$ 1.18), 18-OAc/H-5a $(\delta 2.46)$, $\mathrm{H}-3 / \mathrm{H}-7, \mathrm{H}-7 / \mathrm{H}-9, \mathrm{H}-1 / \mathrm{H}-2 \mathrm{a}(\delta 1.81), \mathrm{H}-3 / \mathrm{H}-2 \mathrm{a}, \mathrm{H}-14 / \mathrm{H}-2 \mathrm{~b}(\delta 1.50)$, $\mathrm{H}-14 / \mathrm{H}_{3}-20$, and $\mathrm{H}-2 \mathrm{~b} / \mathrm{H}-17 \mathrm{~b}(\delta 6.05)$ indicated the relative configurations for the 14-membered ring carbons, which were identical to the X-ray diffraction data of compound 4 . From the above observations, durumolide A (1) was established as $\left(1 R^{*}, 3 R^{*}, 4 S^{*}\right.$, $\left.9 S^{*}, 13 R^{*}, 14 R^{*}, 7 E, 11 E\right)$-18-acetoxy-9,13-dihydroxy-3,4-epoxycembra7,11,15(17)-trien-16,14-olide.

Compound $\mathbf{5}$ has been previously isolated from the soft coral Sinularia gibberosa. ${ }^{17}$ The stereochemistry of $\mathbf{5}$ assigned by NOESY spectrum was compatible with those of $\mathbf{5}$ offered by computergenerated perspective model using MM2 force field calculations (Fig. 4), in which the close contacts of atoms calculated in space were consistent with the NOESY correlations. The NOESY spectrum indicated that $\mathbf{5}$ possessed the same configuration as $\mathbf{4}$ at the $\mathrm{C}-1$, C-3, C-4, and C-14 stereocenters. The significant NOESY correlation differences between $\mathbf{4}$ and $\mathbf{5}$ demonstrated that the hydroxyl group at $\mathrm{C}-13$ of $\mathbf{5}$ possessed the $S$ configuration, which was also identified by Mosher's esterification. ${ }^{18}$ Analysis of the $\Delta \delta_{S-R}$ values (Fig. 2) according to the Mosher model pointed to an $S$ configuration for $\mathrm{C}-13$ of $\mathbf{5}$. Thus, compound $\mathbf{5}$ was formulated as $(1 R, 3 R, 4 S, 13 S$, $14 R, 7 E, 11 E)-13,18$-dihydroxy-3,4-epoxycembra-7,11,15(17)-trien-16, 14-olide.

Compound $\mathbf{6}$ was obtained as a colorless oil, which was analyzed for the molecular formula $\mathrm{C}_{22} \mathrm{H}_{30} \mathrm{O}_{4}$ by HRESIMS coupled with the DEPT and ${ }^{13} \mathrm{C}$ NMR spectroscopic data (Table 2). The presence of an
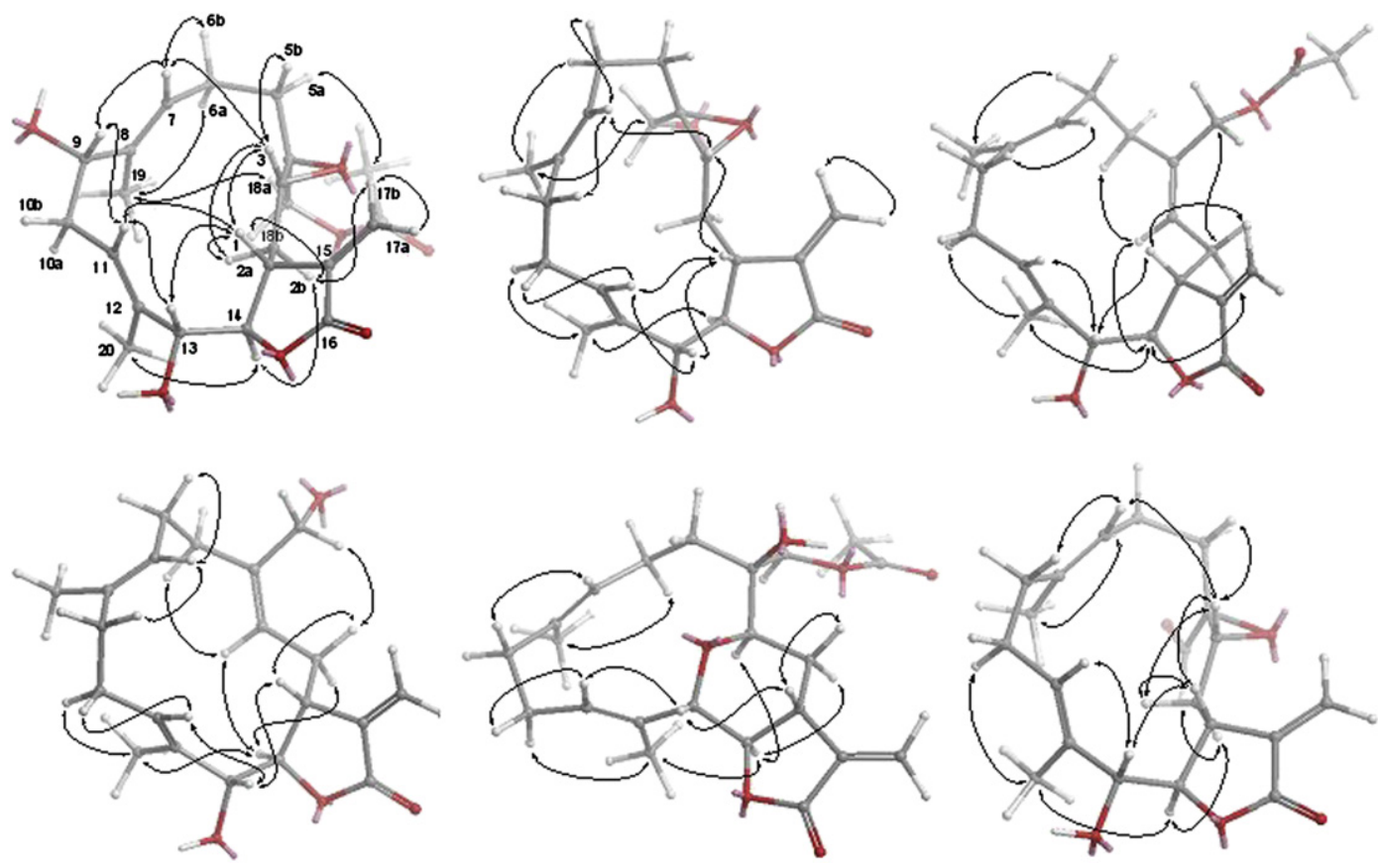

Figure 4. Key NOE correlations and computer-generated perspective model using MM2 force field calculations for 1, 5, 6, and 8-10. 
$\alpha$-methylene- $\gamma$-lactone moiety was indicated from the ${ }^{1} \mathrm{H}$ NMR signals at $\delta 6.32(1 \mathrm{H}, \mathrm{d}, J=1.9 \mathrm{~Hz})$ and $5.73(1 \mathrm{H}, \mathrm{d}, J=1.5 \mathrm{~Hz})$ and ${ }^{13} \mathrm{C}$ NMR signals at $\delta 169.6$ (qC, C-16), 138.4 (qC, C-15), $123.3\left(\mathrm{CH}_{2}, \mathrm{C}-17\right)$, $83.7(\mathrm{CH}, \mathrm{C}-14)$, and $42.0(\mathrm{CH}, \mathrm{C}-1)$. The ${ }^{1} \mathrm{H}$ and ${ }^{13} \mathrm{C}$ NMR spectroscopic data of $\mathbf{6}$ contained resonances for three trisubstituted double bonds at $\mathrm{C}-3$ and $\mathrm{C}-4\left[\delta_{\mathrm{H}} 5.27(\mathrm{t}, J=7.6 \mathrm{~Hz}, 1 \mathrm{H}) ; \delta_{\mathrm{C}} 135.8(\mathrm{qC})\right.$ and $126.6(\mathrm{CH})], \mathrm{C}-7$ and $\mathrm{C}-8\left[\delta_{\mathrm{H}} 4.89(\mathrm{br} \mathrm{t}, J=7.5 \mathrm{~Hz}, 1 \mathrm{H}) ; \delta_{\mathrm{C}} 133.9\right.$ $(\mathrm{qC})$ and $123.5(\mathrm{CH})]$, and $\mathrm{C}-11$ and $\mathrm{C}-12\left[\delta_{\mathrm{H}} 5.36\right.$ (br dd, $J=8.4$, $4.7 \mathrm{~Hz}, 1 \mathrm{H}) ; \delta_{\mathrm{C}} 131.9(\mathrm{qC})$ and $\left.131.3(\mathrm{CH})\right]$. From the above evidences, 6 was suggested to be a bicyclic cembranolide. The assignments of proton and carbon signals were achieved by application of COSY, HSQC, and HMBC experiments (Fig. 1). Metabolite 6 was analogous to those of $7^{12}$ except for the resonances in the vicinity of $C-13$. The exception was that the resonances for the methylene at $\mathrm{C}-13$ were replaced by those of a secondary hydroxyl. The COSY correlations (Fig. 3) from $\mathrm{H}-13$ to $\mathrm{H}-3$ through $\mathrm{H}_{2}-2, \mathrm{H}-1$, and $\mathrm{H}-14$, and $\mathrm{HMBC}$ correlations (Fig. 3) from $\mathrm{H}_{3}-20$ to $\mathrm{C}-11, \mathrm{C}-12$, and $\mathrm{C}-13$ suggested these assignments. The stereochemistry of $\mathbf{6}$ was determined through inspection of the NOESY NMR spectrum as well as a computer-generated lower energy conformation using MM2 force field calculations (Fig. 4). From the NOESY spectrum of 6, H-13 was found to show the NOE correlations with both $\mathrm{H}-1$ and $\mathrm{H}-11$, indicating the $R$ configuration of the secondary hydroxyl attached at $\mathrm{C}-13$. The NOE correlations between $\mathrm{H}_{2}-18 / \mathrm{H}_{2}-2, \mathrm{H}_{3}-19 / \mathrm{H}_{2}-6, \mathrm{H}_{3}-20 / \mathrm{H}_{2}-10$, $\mathrm{H}-3 / \mathrm{H}_{2}-5, \mathrm{H}_{2}-9 / \mathrm{H}-7$, and $\mathrm{H}-11 / \mathrm{H}-13$, respectively, reflected the $E$ geometry of the three trisubstituted double bonds in the molecule. On the basis of the aforementioned results and other detailed NOESY correlations (Fig. 4), the structure of durumolide B (6) was unambiguously elucidated and assigned as $\left(1 R^{*}, 13 R^{*}, 14 R^{*}, 3 E\right.$, 7E,11E)-18-acetoxy-13-hydroxycembra-3,7,11,15(17)-tetraen-16,14olide.

Compound 8 gave a formula of $\mathrm{C}_{20} \mathrm{H}_{28} \mathrm{O}_{4}$, from the interpretation of its HRESIMS and ${ }^{13} \mathrm{C}$ NMR spectroscopic data (Table 2 ). The NMR features (Tables 2 and 3 ) of $\mathbf{8}$ were analogous to those of $\mathbf{6}$ with the exception that the resonances for the primary hydroxyl at $\mathrm{C}-18$ were replaced by those of an acetoxy group. The HMBC correlations from $\mathrm{H}_{2}-18$ to $\mathrm{C}-3, \mathrm{C}-4, \mathrm{C}-5$, and the carbonyl carbon of OAc-18 suggested these assignments. The computermodeled structure of $\mathbf{8}$ was generated by CS Chem 3D version 9.0 using MM2 force field calculations for energy minimization, as shown in Figure 4. The result was consistent with the

Table 3

${ }^{1} \mathrm{H}$ NMR spectral data of compounds 8-10

\begin{tabular}{|c|c|c|c|}
\hline $\mathrm{H \#}$ & $8^{a}$ & $\mathbf{9}^{\mathrm{a}}$ & $10^{b}$ \\
\hline 1 & $2.73 \mathrm{~m}$ & $2.91 \mathrm{~m}$ & $2.76 \mathrm{~m}$ \\
\hline 2 & a: $2.40 \mathrm{~m} ; \mathrm{b}: 2.29 \mathrm{~m}$ & a: $1.99 \mathrm{~m} ; \mathrm{b}: 1.78 \mathrm{~m}$ & $\begin{array}{l}\text { a: } 1.97 \mathrm{dt}(16.8,2.0)^{\mathrm{c}} \text {; } \\
\text { b: } 1.70 \mathrm{~m}\end{array}$ \\
\hline 3 & $5.19 \mathrm{t}(7.5)^{\mathrm{c}}$ & $3.57 \mathrm{br} \mathrm{d}(8.9)^{\mathrm{c}}$ & 3.17 dd $(8.4,2.0)$ \\
\hline 5 & a: $2.26 \mathrm{~m} ; \mathrm{b}: 2.17 \mathrm{~m}$ & a: $1.91 \mathrm{~m} ; \mathrm{b}: 1.72 \mathrm{~m}$ & $\begin{array}{l}\text { a: } 2.51 \mathrm{~m} \\
\text { b: } 1.21 \mathrm{td}(15.2,2.4)\end{array}$ \\
\hline 6 & a: $2.32 \mathrm{~m} ; \mathrm{b}: 2.17 \mathrm{~m}$ & $2.24 \mathrm{~m}$ & a: $2.63 \mathrm{~m} ; \mathrm{b}: 2.16 \mathrm{~m}$ \\
\hline 7 & 4.89 br d $(7.0)$ & 5.19 br t ( 6.4$)$ & 5.05 br t $(7.2)$ \\
\hline 9 & $2.09 \mathrm{~m}$ & $2.23 \mathrm{~m}$ & a: $2.36 \mathrm{~m} ; \mathrm{b}: 2.14 \mathrm{~m}$ \\
\hline 10 & a: $2.38 \mathrm{~m} ; \mathrm{b}: 2.13 \mathrm{~m}$ & a: $2.39 \mathrm{~m} ; \mathrm{b}: 2.25 \mathrm{~m}$ & a: $2.53 \mathrm{~m} ; \mathrm{b}: 2.20 \mathrm{~m}$ \\
\hline 11 & 5.34 br d (5.7) & 5.46 br t $(5.8)$ & 5.46 dd $(10.0,2.8)$ \\
\hline 13 & $3.75 \mathrm{~d}(7.7)$ & $3.83 \mathrm{~d}(8.8)$ & $4.04 \mathrm{br} \mathrm{s}$ \\
\hline 14 & 4.23 dd $(7.7,2.3)$ & $4.27 \mathrm{dd}(8.8,3.4)$ & $4.05 \mathrm{br} \mathrm{d}(6.4)$ \\
\hline 17 & $\begin{array}{l}\text { a: } 6.29 \mathrm{~d}(1.9) ; \\
\text { b: } 5.71 \mathrm{~d}(1.6)\end{array}$ & $\begin{array}{l}\text { a: } 6.32 \mathrm{~d}(2.0) ; \\
\text { b: } 5.76 \mathrm{~d}(2.0)\end{array}$ & $\begin{array}{l}\text { a: } 6.38 \mathrm{~d}(3.2) ; \\
\text { b: } 6.15 \mathrm{~d}(2.8)\end{array}$ \\
\hline 18 & $4.10 \mathrm{~s}$ & $\begin{array}{l}\text { a: } 4.22 \text { d (11.9); } \\
\text { b: } 4.14 \text { d (11.9) }\end{array}$ & $9.34 \mathrm{~d}(0.8)$ \\
\hline 19 & $1.61 \mathrm{~s}$ & $1.67 \mathrm{~s}$ & $1.58 \mathrm{~s}$ \\
\hline 20 & $1.71 \mathrm{~s}$ & $1.78 \mathrm{~s}$ & $1.71 \mathrm{~s}$ \\
\hline OAC & & $2.05 \mathrm{~s}$ & \\
\hline
\end{tabular}

a Spectra were measured in $\mathrm{CDCl}_{3}(300 \mathrm{MHz})$.

b Spectra were measured in $\mathrm{CDCl}_{3}(400 \mathrm{MHz})$.

c $J$ values (in $\mathrm{Hz}$ ) are in parentheses. stereochemistry of $\mathbf{8}$ as established by the NOESY experiment. In order to resolve the absolute stereochemistry of $\mathbf{8}$, we determined the absolute configuration at C-13 using a modified Mosher's esterification. ${ }^{18}$ The bis-(S)- and $(R)-\alpha$-methoxy- $\alpha$-(trifluoromethyl)$\alpha$-phenylacetic (MTPA) esters for $\mathbf{8}$ (8a and $\mathbf{8 b}$, respectively) were prepared by using the corresponding $R-(-)$ - and $S$-(+)-MTPA chloride, respectively. The determination of $\Delta \delta_{S-R}$ values (Fig. 2) for the protons neighboring $\mathrm{C}-13$ led to the assignment of the $R$ configuration at $\mathrm{C}-13$ in $\mathbf{8}$. Thus, durumolide $\mathrm{C}(\mathbf{8})$ was established as $(1 R, 13 R, 14 R, 3 E, 7 E, 11 E)-13,18$-dihydroxycembra-3,7,11,15(17)-tetraen-16,14-olide.

$\left(1 R^{*}, 3 R^{*}, 4 R^{*}, 13 S^{*}, 14 S^{*}, 7 E, 11 E\right)-18$-Acetoxy-4-hydroxy-3,13-epoxycembra-7,11,15(17)-tetraen-16,14-olide (9) was assigned a molecular formula of $\mathrm{C}_{22} \mathrm{H}_{30} \mathrm{O}_{6}$, according to its HRESIMS and NMR spectroscopic data (Tables 2 and 3). To confirm the number of primary or secondary $\mathrm{OH}$ groups, compound $\mathbf{9}$ was submitted to acetylation with $\mathrm{Ac}_{2} \mathrm{O}$ in pyridine at room temperature overnight. The obtained negative result showed that compound 9 didn't possess any primary or secondary $\mathrm{OH}$ groups in the original structure. The position of the ether linkage at $\mathrm{C}-3 / \mathrm{C}-13$ was thus confirmed by the above observations. The acetoxy function positioned at $\mathrm{C}-18$ was confirmed by the $\mathrm{HMBC}$ correlations from $\mathrm{H}_{2}-18$ to $\mathrm{C}-3, \mathrm{C}-4, \mathrm{C}-5$ and the carbonyl carbon of OAc-18. The ${ }^{1} \mathrm{H}-{ }^{1} \mathrm{H}$ COSY spectrum correlations of $\mathbf{9}$ were similar to those of $\mathbf{6}$. These data, together with the ${ }^{1} \mathrm{H}-{ }^{13} \mathrm{C}$ long-range correlations observed in the HMBC experiments (Fig. 3), established the planar structure of $\mathbf{9}$. The relative stereochemistry of $\mathbf{9}$ was deduced from a 2D NOESY experiment, which indicated that $\mathrm{H}-1, \mathrm{H}-11$, and $\mathrm{H}-13$ are located on the same side of the ring system, whereas $\mathrm{H}-3, \mathrm{H}-14$, and $\mathrm{H}_{2}-18$ are oriented toward the opposite side. The computer-modeled structure of 9 was generated by CS Chem 3D version 9.0 using MM2 force field calculations for energy minimization, as shown in Figure 4 . The result was consistent with the stereochemistry of $\mathbf{9}$ as established by NOESY experiments. Accordingly, the structure of durumolide $\mathrm{D}(\mathbf{9})$ was established unambiguously.

Durumolide $\mathrm{E}(\mathbf{1 0})$ analyzed for $\mathrm{C}_{20} \mathrm{H}_{26} \mathrm{O}_{5}$ from HRESIMS and ${ }^{13} \mathrm{C}$ NMR spectroscopic data (Table 2), indicating eight degrees of unsaturation. The IR spectrum of $\mathbf{1 0}$ showed the presence of hydroxy $\left(3457 \mathrm{~cm}^{-1}\right)$, aldehyde functionality $\left(2846\right.$ and $\left.1716 \mathrm{~cm}^{-1}\right)$, and $\alpha$-methylene- $\gamma$-lactone (1767 and $1660 \mathrm{~cm}^{-1}$ ) moieties. The NMR features (Tables 2 and 3 ) of $\mathbf{1 0}$ were similar to those of $\mathbf{4}$, except for the replacement of the oxymethylene by an aldehyde group $\left[\delta_{\mathrm{H}} 9.34(1 \mathrm{H}, \mathrm{d}, J=0.8 \mathrm{~Hz})\right.$ and $\left.\delta_{\mathrm{C}} 199.3(\mathrm{CH})\right]$ at $\mathrm{C}-18$. This was supported by HMBC correlations (Fig. 3) from $\mathrm{H}-18$ to C-3, C-4, and $\mathrm{C}-5$. The relative stereochemistry and the detailed ${ }^{1} \mathrm{H}$ NMR spectroscopic data assignment of $\mathbf{1 0}$ were determined mainly by the assistance of the NOESY experiment (Fig. 4). The NOESY spectrum indicated that $\mathbf{1 0}$ possessed the similar configurations for each ring junction and chiral center as 4 at C-1, C-3, C-4, C-13, and C-14. On the basis of the above observations and other detailed NOESY correlations (Fig. 4), compound $\mathbf{1 0}$ was fully elucidated as $\left(1 R^{*}, 3 R^{*}, 4 S^{*}\right.$, $\left.13 S^{*}, 14 R^{*}, 7 E, 11 E\right)$-13-hydroxy-18-oxo-3,4-epoxycembra-7,11,15(17)trien-16,14-olide.

Noteworthy is the conclusion concerning the bicyclic ring junction in these isolated metabolites possessing the $\alpha$-methylene$\gamma$-lactone moiety. An X-ray crystallographic analysis of compound 4 proved the presence of a trans-fused lactone ring. Biosynthetically, the tetrahydro- $2 \mathrm{H}$-pyran ring of compound $\mathbf{9}$ may be formed by the hydroxyl at $\mathrm{C}-13$ attacking to $\mathrm{C}-3$ by acid-catalyzed ring-opening of the 3,4-epoxide.

Compounds 1-6, 8, and 10 revealed greater antibacterial potential than the positive control (ampicillin) against Salmonella enteritidis. Compound $\mathbf{3}$ exhibited significant antibacterial activity at a concentration of $50 \mu \mathrm{g} /$ disk; compounds 2, 4-6, and 8 at a concentration of $100 \mu \mathrm{g} /$ disk and compounds $\mathbf{1}$ and $\mathbf{1 0}$ at a concentration of $200 \mu \mathrm{g} /$ disk. Compounds 7, 9, and ampicillin exhibited 

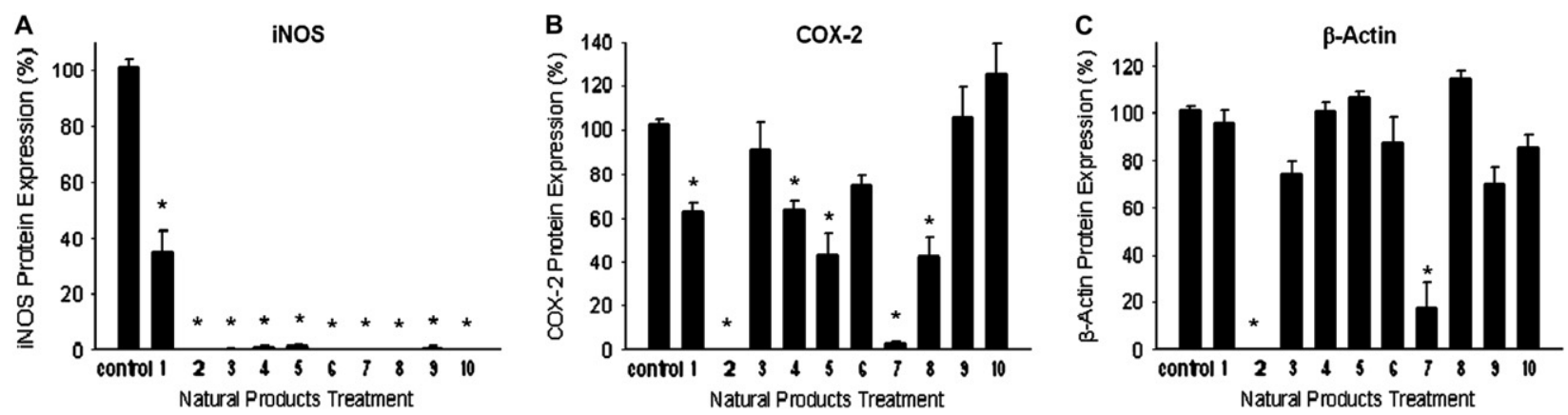

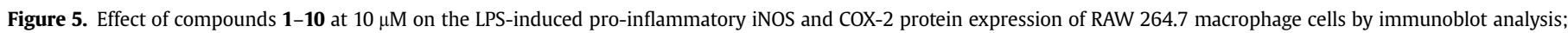

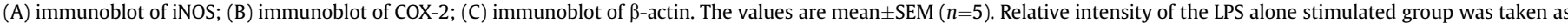
$100 \%$. "Significantly different from LPS-stimulated (control) group $\left({ }^{*} P<0.05\right)$.

significant antibacterial activity at a concentration of $250 \mu \mathrm{g} /$ disk. The present result suggested that the presence of $\alpha$-methylene$\gamma$-lactone moiety is important for significant activity against S. enteritidis. ${ }^{19}$ However, the results for inhibition of HCMV endonuclease activity assay are all negative at a concentration of $1 \mathrm{mg} / \mathrm{mL}$.

In vitro anti-inflammatory activity of compounds 1-10 was tested using LPS-stimulated cell. Stimulation of RAW 264.7 cell with LPS resulted in up-regulation of the pro-inflammatory iNOS and COX-2 protein (Fig. 5). Compounds $\mathbf{1}, \mathbf{4}, \mathbf{5}$, and $\mathbf{8}$ at concentration of $10 \mu \mathrm{M}$, significantly reduced the levels of the iNOS protein $(34.7 \pm 7.9 \%, 0.9 \pm 0.3 \%, 1.4 \pm 0.2 \%$, and $0.0 \pm 0.0 \%$, respectively) and COX-2 protein $(62.5 \pm 4.3 \%, 63.7 \pm 4.0 \%, 42.9 \pm 10.1 \%$, and $42.5 \pm 8.6 \%$, respectively) compare with the control cells (LPS alone). Under the same concentration, compounds 3, 6, 9, and 10 did not inhibit the COX-2 protein expression, but significantly inhibited iNOS protein expression $(0.2 \pm 0.3 \%, 0.0 \pm 0.1 \%, 0.5 \pm 0.7 \%$, and $0.1 \pm 0.1$, respectively, compare with control cells) by LPS stimulation. Moreover, the house keeping protein $\beta$-actin was not changed by the presence of compounds 1, 3-6, and 8-10 at the same concentration. Both compounds $\mathbf{2}$ and $\mathbf{7}$ significantly inhibited pro-inflammatory iNOS and COX-2 protein expression, however, it presented cytotoxic activity for significant inhibition of $\beta$-actin protein expression. Under the same experimental condition, $10 \mu \mathrm{M}$ CAPE (caffeic acid phenylthyl ester; Sigma Chemical. Company, St. Louis, MO) reduced the levels of the iNOS and COX-2 protein to $1.5 \pm 2.1 \%$ and $70.2 \pm 11.5 \%$, respectively, relative to the control cells stimulated with LPS. The primary anti-inflammatory results suggested that the existence of $\alpha$-methylene- $\gamma$-lactone moiety is required for the observed activity against LPS-stimulated RAW 264.7 cell.

\section{Experimental}

\subsection{General experimental procedures}

Optical rotations were determined with a JASCO P1020 digital polarimeter. IR spectra were recorded on a JASCO FT/IR-4100 infrared spectrophotometer. UV spectra were obtained on a JASCO V-650 spectrophotometer. The NMR spectra were recorded on a Bruker Advance $300 \mathrm{NMR}$ spectrometer at $300 \mathrm{MHz}$ for ${ }^{1} \mathrm{H}$ and $75 \mathrm{MHz}$ for ${ }^{13} \mathrm{C}$ or on a Varian MR $400 \mathrm{NMR}$ at $400 \mathrm{MHz}$ for ${ }^{1} \mathrm{H}$ and $100 \mathrm{MHz}$ for ${ }^{13} \mathrm{C}$, respectively, using $\mathrm{CDCl}_{3}$ with TMS as internal standard. Chemical shifts are given in $\delta$ (ppm) and coupling constants in hertz. ESIMS were recorded by ESI FT-MS on a Bruker APEX II mass spectrometer. The crystallographic data were collected on a Rigaku AFC7S diffractometer using graphite-monochromated Mo K $\alpha$ radiation. Si gel 60 (Merck, 230-400 mesh) and LiChroprep RP-18 (Merck, 40-63 $\mu \mathrm{m}$ ) were used for column chromatography. Precoated Si gel plates (Merck, Kieselgel $60 \mathrm{~F}_{254}$,
$0.25 \mathrm{~mm}$ ) and precoated RP-18 $\mathrm{F}_{254 \mathrm{~s}}$ plates (Merck, 1.05560) were used for analytical TLC analyses. High-performance liquid chromatography (HPLC) was carried out using a Hitachi L-7100 pump equipped with a Hitachi L-7400 UV detector at $220 \mathrm{~nm}$ and a semi-preparative reversed-phase column (Merck, Hibar Purospher RP-18e, $5 \mu \mathrm{m}, 250 \times 10 \mathrm{~mm}) . S$-(+)- $\alpha$-Methoxy- $\alpha$-trifluoromethylphenylacetyl and $R-(-)-\alpha$-methoxy- $\alpha$-trifluoromethylphenylacetyl chloride were obtained from ACROS Organics (Geel, Belgium).

\subsection{Animal materials}

The soft coral $L$. durum was collected by hand using scuba at Dongsha Islands located in northeastern South China Sea in April 2007, at a depth of $8 \mathrm{~m}$, and was stored in a freezer for 2 months until extraction. This soft coral was identified by one of the authors (C.-F.D.). A voucher specimen (TS-13) was deposited in the Department of Marine Biotechnology and Resources, National Sun Yat-sen University.

\subsection{Extraction and isolation}

The frozen soft coral (1.2 kg) was chopped into small pieces and extracted with acetone for $24 \mathrm{~h}$ at room temperature. The quantity of solvent used for each extraction $(2.0 \mathrm{~L})$ was at least three times the amount of the soft coral material used $(1.2 \mathrm{~kg})$. The acetone extracts were evaporated to dryness under reduced pressure. Then, the acetone extract was partitioned between EtOAc and $\mathrm{H}_{2} \mathrm{O}$. The resulting EtOAc extract ( $30.0 \mathrm{~g}$ ) was subjected to column chromatography on silica gel using $n$-hexane, $n$-hexane-EtOAc, and EtOAc$\mathrm{MeOH}$ mixtures of increasing polarity for elution, to furnish 40 fractions. ${ }^{1} \mathrm{H}$ NMR spectroscopy was employed to detect the terpenoid-rich fractions. Duplicate samples $(20 \mathrm{mg})$ of fraction 12 $(0.73 \mathrm{~g})$ eluted with $n$-hexane-EtOAc $(4: 1)$ was further separated by preparative TLC using $n$-hexane-EtOAc (6:1) to yield 7 (12 mg). Fraction $17(0.14 \mathrm{~g})$ eluted with $n$-hexane-EtOAc (1:6) was further purified by reversed-phase HPLC using $\mathrm{MeOH}-\mathrm{H}_{2} \mathrm{O}(75: 25)$ to afford 2 (15 mg), 3 (24 mg), 6 (4 mg), and 9 (18 mg). Fraction 18 $(2.16 \mathrm{~g})$ eluted with $n$-hexane-EtOAc (1:8) was fractionated over Sephadex $\mathrm{LH}-20(100 \% \mathrm{MeOH})$ to produce 14 subfractions. A subfraction 18-11 (202 mg) was subjected to column chromatography on reversed-phase $\mathrm{C}-18$ gel column eluting with $50 \% \mathrm{MeOH}$ in $\mathrm{H}_{2} \mathrm{O}$ to afford a mixture ( $90 \mathrm{mg}$ ) that was further purified by reversedphase HPLC using $70 \% \mathrm{MeOH}$ in $\mathrm{H}_{2} \mathrm{O}$ to give $4(24 \mathrm{mg}$ ) and 5 $(18 \mathrm{mg})$. Fraction 19 (1.18 g) eluted with $n$-hexane-EtOAc ( $1: 10)$ was subjected to a silica gel column using $n$-hexane-EtOAc mixtures of increasing polarity for elution, to give 10 subfractions. Subfraction $19-5$ (336 mg) eluted with $n$-hexane-EtOAc (1:2) was subjected to a reversed-phase $\mathrm{C}-18$ gel eluting with $70 \% \mathrm{MeOH}$ in $\mathrm{H}_{2} \mathrm{O}$ to afford a mixture $(214 \mathrm{mg}$ ) that was further purified by 
reversed-phase $\mathrm{HPLC}$ using $65 \% \mathrm{MeOH}$ in $\mathrm{H}_{2} \mathrm{O}$ to give $\mathbf{1}$ (2 mg). Similarly, compound $\mathbf{1 0}(3 \mathrm{mg})$ was obtained by separation of a subfraction 19-8 (48 mg) eluted with $n$-hexane-EtOAc (1:4) on a reversed-phase $\mathrm{HPLC}$ eluting with $75 \% \mathrm{MeOH}$ in $\mathrm{H}_{2} \mathrm{O}$. Subfraction 19-6 (202 mg) eluted with $n$-hexane-EtOAc (1:3) was subjected to column chromatography on reversed-phase C-18 gel eluting with $65 \% \mathrm{MeOH}$ in $\mathrm{H}_{2} \mathrm{O}$ to afford a mixture $(138 \mathrm{mg})$ that was further purified by reversed-phase HPLC using $70 \% \mathrm{MeOH}$ in $\mathrm{H}_{2} \mathrm{O}$ to give 8 (10 mg).

\subsubsection{Durumolide A (1)}

Colorless, viscous oil; $[\alpha]_{\mathrm{D}}^{24}+93.0\left(\right.$ c $\left.0.2, \mathrm{CHCl}_{3}\right) ; \mathrm{UV}(\mathrm{MeOH}) \lambda_{\max }$ $(\log \varepsilon) 208$ (3.76) nm; IR (KBr) $\nu_{\max } 3458,2952,1765,1745,1663$, $1442,1378,1267,1244,1128,1049,952 \mathrm{~cm}^{-1} ;{ }^{1} \mathrm{H}$ NMR and ${ }^{13} \mathrm{C}$ NMR data, see Tables 1 and 2; ESIMS $m / z 429$ [M+Na] ${ }^{+}$; HRESIMS $m / z$ $429.1890[\mathrm{M}+\mathrm{Na}]^{+}\left(\right.$calcd for $\mathrm{C}_{22} \mathrm{H}_{30} \mathrm{O}_{7} \mathrm{Na} 429.1889$ ).

\subsubsection{Durumolide B (6)}

Colorless, viscous oil; $[\alpha]_{\mathrm{D}}^{24}+41.5\left(c 0.4, \mathrm{CHCl}_{3}\right) ; \mathrm{UV}(\mathrm{MeOH}) \lambda_{\max }$ $(\log \varepsilon) 209$ (3.85) nm; IR (KBr) $\nu_{\max } 3448,2952,1762,1744,1660$, 1439, 1383, 1234, 1128, 1049, $952 \mathrm{~cm}^{-1}$; ${ }^{1} \mathrm{H}$ NMR and ${ }^{13} \mathrm{C}$ NMR data, Tables 1 and 2; ESIMS $m / z 397[\mathrm{M}+\mathrm{Na}]^{+}$; HRESIMS $m / z 397.1990$ $[\mathrm{M}+\mathrm{Na}]^{+}$(calcd for $\mathrm{C}_{22} \mathrm{H}_{30} \mathrm{O}_{4} \mathrm{Na} 397.1991$ ).

\subsubsection{Durumolide $C(\mathbf{8})$}

Colorless, viscous oil; $[\alpha]_{D}^{24}+15.4\left(c 1.0, \mathrm{CHCl}_{3}\right) ; \mathrm{UV}(\mathrm{MeOH}) \lambda_{\max }$ $(\log \varepsilon) 208$ (3.72) nm; IR (KBr) $\nu_{\max } 3453,2948,1767,1660,1442$, 1383, 1244, 1128, 1044, $956 \mathrm{~cm}^{-1} ;{ }^{1} \mathrm{H}$ NMR and ${ }^{13} \mathrm{C}$ NMR data, see Tables 2 and 3; ESIMS $m / z 355[\mathrm{M}+\mathrm{Na}]^{+}$; HRESIMS $m / z 355.1887$ $[\mathrm{M}+\mathrm{Na}]^{+}$(calcd for $\mathrm{C}_{20} \mathrm{H}_{28} \mathrm{O}_{4} \mathrm{Na} 355.1885$ ).

\subsubsection{Durumolide D $(\mathbf{9})$}

Colorless, viscous oil; $[\alpha]_{\mathrm{D}}^{24}+10.2\left(c \mathrm{c} .8, \mathrm{CHCl}_{3}\right)$; $\mathrm{UV}(\mathrm{MeOH}) \lambda_{\max }$ $(\log \varepsilon) 210(3.78) \mathrm{nm}$; IR $(\mathrm{KBr}) \nu_{\max } 3453,2952,1767,1744,1660$, 1442, 1378, 1267, 1244, 1142, 1044, $947 \mathrm{~cm}^{-1} ;{ }^{1} \mathrm{H}$ NMR and ${ }^{13} \mathrm{C}$ NMR data, see Tables 2 and 3; ESIMS $m / z 413$ [M+Na] ${ }^{+}$; HRESIMS $m / z$ $413.1942[\mathrm{M}+\mathrm{Na}]^{+}$(calcd for $\mathrm{C}_{22} \mathrm{H}_{30} \mathrm{O}_{6} \mathrm{Na} 413.1940$ ).

\subsubsection{Durumolide E (10)}

Colorless, viscous oil; $[\alpha]_{\mathrm{D}}^{24}+32.0\left(c 0.3, \mathrm{CHCl}_{3}\right) ; \mathrm{UV}(\mathrm{MeOH}) \lambda_{\max }$ $(\log \varepsilon) 208$ (3.74) nm; IR (KBr) $\nu_{\max } 3457,2952,2846,1767,1716$, $1660,1442,1378,1244,1044,952 \mathrm{~cm}^{-1} ;{ }^{1} \mathrm{H}$ NMR and ${ }^{13} \mathrm{C}$ NMR data, see Tables 2 and 3; ESIMS $m / z 369[\mathrm{M}+\mathrm{Na}]^{+}$; HRESIMS $m / z$ $369.1681[\mathrm{M}+\mathrm{Na}]^{+}$(calcd for $\mathrm{C}_{20} \mathrm{H}_{26} \mathrm{O}_{5} \mathrm{Na} 369.1678$ ).

\subsection{Preparation of $(R)$ - and (S)-MTPA esters of 3}

Duplicate (1.0 mg) samples of $\mathbf{3}$ were prepared for both $(R)$ - and $(S)$-MTPA chloride acylation reactions. In separate vials, the samples were dissolved in $0.5 \mathrm{~mL}$ of dry pyridine and allowed to react overnight at room temperature with $(R)$ - and $(S)$-MTPA chloride (one drop), respectively. The reaction was quenched by the addition of $1.0 \mathrm{~mL}$ of $\mathrm{H}_{2} \mathrm{O}$, followed by extraction with EtOAc $(3 \times 1.0 \mathrm{~mL})$. The EtOAc-soluble layers were combined, dried over anhydrous $\mathrm{MgSO}_{4}$, and evaporated. The residue was subjected to a short silica gel column eluting with $n$-hexane-EtOAc $(5: 1)$ to yield $(S)$-MTPA ester (3a) (0.6 mg). The ( $R$ )-MTPA ester (3b) ( $0.4 \mathrm{mg}$ ) was prepared with $(S)$-MTPA chloride according to the same procedure as described above. Selected ${ }^{1} \mathrm{H} \mathrm{NMR}\left(\mathrm{CDCl}_{3}, 300 \mathrm{MHz}\right)$ of $\mathbf{3 a}: \delta_{\mathrm{H}} 7.33-7.47(5 \mathrm{H}$, $\mathrm{m}, \mathrm{Ph}), 6.25$ (1H, d, $J=2.7 \mathrm{~Hz}, \mathrm{H}-17 \mathrm{a}), 5.92$ (1H, d, $J=2.3 \mathrm{~Hz}, \mathrm{H}-17 \mathrm{~b})$, $5.55(1 \mathrm{H}$, br dd, $J=8.9,3.2 \mathrm{~Hz}, \mathrm{H}-11), 5.36(1 \mathrm{H}, \mathrm{d}, J=9.3 \mathrm{~Hz}, \mathrm{H}-13)$, $4.95(1 \mathrm{H}$, br t, $J=7.0 \mathrm{~Hz}, \mathrm{H}-7), 4.16(1 \mathrm{H}$, br dd, $J=8.8,6.8 \mathrm{~Hz}, \mathrm{H}-14)$, 4.19 ( $1 \mathrm{H}, \mathrm{d}, J=12.1 \mathrm{~Hz}, \mathrm{H}-18 \mathrm{a}$ ), 3.83 ( $1 \mathrm{H}, \mathrm{d}, J=12.1 \mathrm{~Hz}, \mathrm{H}-18 \mathrm{~b}), 3.48$ (3H, s, OCH3), $2.78(1 \mathrm{H}, \mathrm{m}, \mathrm{H}-3), 2.78(1 \mathrm{H}, \mathrm{m}, \mathrm{H}-1), 2.45(1 \mathrm{H}, \mathrm{m}$, H-10a), 2.02 (3H, s, 18-OAc), 1.73 (1H, dt, $J=14.6,2.8 \mathrm{~Hz}, \mathrm{H}-2 \mathrm{a}), 1.69$ (3H, s, Me-20), 1.57 (3H, s, Me-19), $1.31(1 \mathrm{H}, \mathrm{td}, J=12.4,3.5 \mathrm{~Hz}$,
$\mathrm{H}-5 \mathrm{~b})$. Selected ${ }^{1} \mathrm{H} \mathrm{NMR}\left(\mathrm{CDCl}_{3}, 300 \mathrm{MHz}\right)$ of $\mathbf{3 b}: \delta_{\mathrm{H}} 7.33-7.49(5 \mathrm{H}$, $\mathrm{m}, \mathrm{Ph}), 6.27(1 \mathrm{H}, \mathrm{d}, J=2.7 \mathrm{~Hz}, \mathrm{H}-17 \mathrm{a}), 5.96(1 \mathrm{H}, \mathrm{d}, J=2.3 \mathrm{~Hz}, \mathrm{H}-17 \mathrm{~b})$, $5.50(1 \mathrm{H}$, br dd, $J=8.9,3.2 \mathrm{~Hz}, \mathrm{H}-11), 5.26(1 \mathrm{H}, \mathrm{d}, J=9.3 \mathrm{~Hz}, \mathrm{H}-13)$, $4.92(1 \mathrm{H}$, br t, $J=7.0 \mathrm{~Hz}, \mathrm{H}-7), 4.18(1 \mathrm{H}, \mathrm{br} \mathrm{dd}, J=8.8,6.8 \mathrm{~Hz}, \mathrm{H}-14)$, $4.20(1 \mathrm{H}, \mathrm{d}, J=12.1 \mathrm{~Hz}, \mathrm{H}-18 \mathrm{a}), 3.82(1 \mathrm{H}, \mathrm{d}, J=12.1 \mathrm{~Hz}, \mathrm{H}-18 \mathrm{~b}), 3.56$ (3H, s, OCH3), $2.76(1 \mathrm{H}, \mathrm{m}, \mathrm{H}-3), 2.76(1 \mathrm{H}, \mathrm{m}, \mathrm{H}-1), 2.37(1 \mathrm{H}, \mathrm{m}$, H-10a), 2.03 (3H, s, 18-OAc), 1.76 (1H, dt, $J=14.6,2.8 \mathrm{~Hz}, \mathrm{H}-2 \mathrm{a}), 1.53$ (3H, s, Me-20), 1.42 (3H, s, Me-19), 1.26 (1H, td, $J=12.4,3.5 \mathrm{~Hz}$, $\mathrm{H}-5 \mathrm{~b})$.

\subsection{Preparation of bis-(R)- and (S)-MTPA esters of 4,5 , and 8}

In the same manner as shown above, two aliquots of $4(1.0 \mathrm{mg})$ were dissolved in dry pyridine $(0.5 \mathrm{~mL})$ and allowed to react overnight with $(R)$ - and $(S)$-MTPA chloride (one drop), affording the bis- $(S)$ - and bis- $(R)$-MTPA ester $\mathbf{4 a}(0.4 \mathrm{mg})$ and $\mathbf{4 b}(0.3 \mathrm{mg})$, respectively. For compounds $\mathbf{5}$ and $\mathbf{8}$, the same procedure as above was carried out to obtain the corresponding bis-(S)- and bis- $(R)-$ MTPA esters (5a, 5b, 8a, and $\mathbf{8 b}$, respectively). Selected ${ }^{1} \mathrm{H}$ $\mathrm{NMR}\left(\mathrm{CDCl}_{3}, 300 \mathrm{MHz}\right)$ of 4a: $\delta_{\mathrm{H}} 7.42-7.61(10 \mathrm{H}, \mathrm{m}, \mathrm{Ph} \times 2), 6.32(1 \mathrm{H}$, d, $J=3.0 \mathrm{~Hz}, \mathrm{H}-17 \mathrm{a}), 5.97$ (1H, d, $J=2.5 \mathrm{~Hz}, \mathrm{H}-17 \mathrm{~b}), 5.61$ (1H, br dd, $J=8.6,4.1 \mathrm{~Hz}, \mathrm{H}-11$ ), 5.45 (1H, d, $J=9.0 \mathrm{~Hz}, \mathrm{H}-13), 4.94$ (1H, br t, $J=$ $6.8 \mathrm{~Hz}, \mathrm{H}-7), 4.42(1 \mathrm{H}, \mathrm{d}, J=12.2 \mathrm{~Hz}, \mathrm{H}-18 \mathrm{a}), 4.22(1 \mathrm{H}, \mathrm{d}, J=12.2 \mathrm{~Hz}$, $\mathrm{H}-18 \mathrm{~b}), 4.10(1 \mathrm{H}, \mathrm{br} \mathrm{dd}, J=15.7,8.9 \mathrm{~Hz}, \mathrm{H}-14), 3.56(3 \mathrm{H}, \mathrm{s}, \mathrm{OCH} 3)$, 3.53 (3H, s, OCH3), 2.82 (1H, m, H-3), $2.82(1 \mathrm{H}, \mathrm{m}, \mathrm{H}-1), 1.76(1 \mathrm{H}, \mathrm{dt}$, $J=14.7,3.2 \mathrm{~Hz}, \mathrm{H}-2 \mathrm{a}), 1.67$ (3H, s, Me-20), 1.62 (3H, s, Me-19). Selected ${ }^{1} \mathrm{H}$ NMR $\left(\mathrm{CDCl}_{3}, 300 \mathrm{MHz}\right)$ of $4 \mathbf{b}: \delta_{\mathrm{H}} 7.42-7.61(10 \mathrm{H}, \mathrm{m}$, $\mathrm{Ph} \times 2), 6.33(1 \mathrm{H}, \mathrm{d}, J=3.0 \mathrm{~Hz}, \mathrm{H}-17 \mathrm{a}), 6.00(1 \mathrm{H}, \mathrm{d}, J=2.5 \mathrm{~Hz}, \mathrm{H}-17 \mathrm{~b})$, $5.53(1 \mathrm{H}$, br dd, $J=8.6,4.1 \mathrm{~Hz}, \mathrm{H}-11), 5.36(1 \mathrm{H}, \mathrm{d}, J=9.0 \mathrm{~Hz}, \mathrm{H}-13)$, $4.96(1 \mathrm{H}, \mathrm{br} \mathrm{t}, J=6.8 \mathrm{~Hz}, \mathrm{H}-7), 4.46(1 \mathrm{H}, \mathrm{d}, J=12.2 \mathrm{~Hz}, \mathrm{H}-18 \mathrm{a}), 4.17$ ( $1 \mathrm{H}, \mathrm{d}, J=12.2 \mathrm{~Hz}, \mathrm{H}-18 \mathrm{~b}), 4.15$ (1H, br dd, $J=15.7,8.9 \mathrm{~Hz}, \mathrm{H}-14), 3.65$ (3H, s, OCH3), $3.55(3 \mathrm{H}, \mathrm{s}, \mathrm{OCH} 3), 2.83(1 \mathrm{H}, \mathrm{m}, \mathrm{H}-3), 2.83(1 \mathrm{H}, \mathrm{m}$, $\mathrm{H}-1), 1.84(1 \mathrm{H}, \mathrm{dt}, J=14.7,3.2 \mathrm{~Hz}, \mathrm{H}-2 \mathrm{a}), 1.59$ (3H, s, Me-20), $1.45(3 \mathrm{H}$, $\mathrm{s}$, Me-19). Selected ${ }^{1} \mathrm{H}$ NMR( $\left(\mathrm{CDCl}_{3}, 400 \mathrm{MHz}\right)$ of $\mathbf{5 a}: \delta_{\mathrm{H}} 7.39-7.52$ $(10 \mathrm{H}, \mathrm{m}, \mathrm{Ph} \times 2), 6.24(1 \mathrm{H}, \mathrm{d}, J=3.2 \mathrm{~Hz}, \mathrm{H}-17 \mathrm{a}), 5.91(1 \mathrm{H}, \mathrm{d}, J=2.8 \mathrm{~Hz}$, $\mathrm{H}-17 \mathrm{~b}), 5.54(1 \mathrm{H}, \mathrm{br} \mathrm{s}, \mathrm{H}-13), 4.90(1 \mathrm{H}, \mathrm{br} \mathrm{dd}, J=8.4,4.0 \mathrm{~Hz}, \mathrm{H}-11)$, $4.83(1 \mathrm{H}$, br t, $J=7.2 \mathrm{~Hz}, \mathrm{H}-7), 4.40(1 \mathrm{H}, \mathrm{d}, J=12.0 \mathrm{~Hz}, \mathrm{H}-18 \mathrm{a}), 4.23$ (1H, d, $J=12.0 \mathrm{~Hz}, \mathrm{H}-18 \mathrm{~b}), 4.18$ (1H, dd, $J=6.4,2.0 \mathrm{~Hz}, \mathrm{H}-14), 3.54$ (3H, s, OCH3), $3.51(3 \mathrm{H}, \mathrm{s}, \mathrm{OCH} 3), 3.09(1 \mathrm{H}, \mathrm{m}, \mathrm{H}-1), 2.75(1 \mathrm{H}, \mathrm{dd}$, $J=7.6,2.8 \mathrm{~Hz}, \mathrm{H}-3$ ), 2.38 (1H, m, H-10a), 2.23 (1H, m, H-10b), 2.11 (1H, m, H-6a), 2.10 (1H, m, H-5a), 2.05 (1H, m, H-6b), 1.98 (1H, m, H-9a), 1.84 (1H, m, H-9b), 1.75 (1H, dt, $J=14.8,3.6 \mathrm{~Hz}, \mathrm{H}-2 \mathrm{a}), 1.69$ (3H, s, Me-20), 1.52 (3H, s, Me-19), 1.49 (1H, m, H-2b), 1.23 (1H, td, $J=14.0,3.2 \mathrm{~Hz}, \mathrm{H}-5 \mathrm{~b})$. Selected ${ }^{1} \mathrm{H} \mathrm{NMR}\left(\mathrm{CDCl}_{3}, 400 \mathrm{MHz}\right)$ of $\mathbf{5 b}: \delta_{\mathrm{H}}$ 7.40-7.62 (10H, m, Ph $\times 2), 6.21(1 \mathrm{H}, \mathrm{d}, J=3.2 \mathrm{~Hz}, \mathrm{H}-17 \mathrm{a}), 5.90(1 \mathrm{H}, \mathrm{d}$, $J=2.8 \mathrm{~Hz}, \mathrm{H}-17 \mathrm{~b}), 5.65(1 \mathrm{H}, \mathrm{br} \mathrm{s}, \mathrm{H}-13), 5.29(1 \mathrm{H}, \mathrm{br} \mathrm{dd}, J=8.4,4.0 \mathrm{~Hz}$, $\mathrm{H}-11$ ), 4.97 (1H, br t, $J=7.2 \mathrm{~Hz}, \mathrm{H}-7), 4.50(1 \mathrm{H}, \mathrm{d}, J=12.0 \mathrm{~Hz}, \mathrm{H}-18 \mathrm{a})$, $4.16(1 \mathrm{H}, \mathrm{dd}, J=6.4,2.0 \mathrm{~Hz}, \mathrm{H}-14), 4.13(1 \mathrm{H}, \mathrm{d}, J=12.0 \mathrm{~Hz}, \mathrm{H}-18 \mathrm{~b})$, 3.57 (3H, s, OCH3), 3.46 (3H, s, OCH3), $3.11(1 \mathrm{H}, \mathrm{m}, \mathrm{H}-1), 2.80(1 \mathrm{H}$, $\mathrm{dd}, J=7.6,2.8 \mathrm{~Hz}, \mathrm{H}-3$ ), 2.47 (1H, m, H-10a), 2.31 (1H, m, H-10b), 2.19 (1H, m, H-6a), 2.12 (1H, m, H-5a), 2.07 (1H, m, H-6b), $2.02(1 \mathrm{H}, \mathrm{m}$, $\mathrm{H}-9 \mathrm{a}), 1.90$ (1H, m, H-9b), 1.79 (1H, dt, $J=14.8,3.6 \mathrm{~Hz}, \mathrm{H}-2 \mathrm{a}), 1.77$ (3H, s, Me-20), 1.57 (3H, s, Me-19), 1.48 (1H, m, H-2b), 1.19 (1H, td, $J=14.0,3.2 \mathrm{~Hz}, \mathrm{H}-5 \mathrm{~b})$. Selected ${ }^{1} \mathrm{H} \mathrm{NMR}\left(\mathrm{CDCl}_{3}, 400 \mathrm{MHz}\right)$ of $8 \mathbf{a}: \delta_{\mathrm{H}}$ 7.38-7.54 (10H, m, Ph $\times 2), 6.29(1 \mathrm{H}, \mathrm{d}, J=2.0 \mathrm{~Hz}, \mathrm{H}-17 \mathrm{a}), 5.67(1 \mathrm{H}, \mathrm{d}$, $J=1.2 \mathrm{~Hz}, \mathrm{H}-17 \mathrm{~b}), 5.45$ (1H, br t, $J=8.0 \mathrm{~Hz}, \mathrm{H}-11), 5.28(1 \mathrm{H}$, br t, $J=7.2 \mathrm{~Hz}, \mathrm{H}-3), 5.12(1 \mathrm{H}, \mathrm{d}, J=7.6 \mathrm{~Hz}, \mathrm{H}-13), 4.82(1 \mathrm{H}, \mathrm{d}, J=12.0 \mathrm{~Hz}$, $\mathrm{H}-18 \mathrm{a}), 4.79(1 \mathrm{H}, \mathrm{br} \mathrm{d}, J=6.8 \mathrm{~Hz}, \mathrm{H}-7), 4.69(1 \mathrm{H}, \mathrm{d}, J=12.0 \mathrm{~Hz}, \mathrm{H}-$ $18 \mathrm{~b}), 4.20$ (1H, dd, $J=7.6,2.0 \mathrm{~Hz}, \mathrm{H}-14), 3.53(3 \mathrm{H}, \mathrm{s}, \mathrm{OCH} 3), 3.50(3 \mathrm{H}$, s, OCH3), 2.68 (1H, m, H-1), 2.36 (1H, m, H-2a), 2.31 (1H, m, H-10a), 2.23 (1H, m, H-2b), 2.20 (1H, m, H-10b), 1.68 (3H, s, Me-20), 1.59 (3H, s, Me-19). Selected ${ }^{1} \mathrm{H}$ NMR $\left(\mathrm{CDCl}_{3}, 400 \mathrm{MHz}\right)$ of $\mathbf{8 b}: \delta_{\mathrm{H}} 7.36-$ $7.52(10 \mathrm{H}, \mathrm{m}, \mathrm{Ph} \times 2), 6.32(1 \mathrm{H}, \mathrm{d}, J=2.0 \mathrm{~Hz}, \mathrm{H}-17 \mathrm{a}), 5.72(1 \mathrm{H}, \mathrm{d}$, $J=1.2 \mathrm{~Hz}, \mathrm{H}-17 \mathrm{~b}), 5.24(1 \mathrm{H}, \mathrm{br} \mathrm{t}, J=7.2 \mathrm{~Hz}, \mathrm{H}-3), 5.19(1 \mathrm{H}, \mathrm{br} \mathrm{t}$, $J=8.0 \mathrm{~Hz}, \mathrm{H}-11), 4.96(1 \mathrm{H}, \mathrm{d}, J=7.6 \mathrm{~Hz}, \mathrm{H}-13), 4.74$ (2H, br s, H-18), $4.73(1 \mathrm{H}, \mathrm{br} \mathrm{d}, J=6.8 \mathrm{~Hz}, \mathrm{H}-7), 4.22(1 \mathrm{H}, \mathrm{dd}, J=7.6,2.0 \mathrm{~Hz}, \mathrm{H}-14), 3.63$ 
(3H, s, OCH3), 3.50 (3H, s, OCH3), 2.70 (1H, m, H-1), 2.37 (1H, m, H2a), 2.22 (1H, m, H-2b), 2.18 (1H, m, H-10a), 2.11 (1H, m, H-10b), 1.61 (3H, s, Me-20), 1.55 (3H, s, Me-19).

\subsection{Crystallographic data and $X$-ray structure analysis of compound $4^{20}$}

A suitable colorless crystal $\left(0.8 \times 0.8 \times 0.6 \mathrm{~mm}^{3}\right)$ of $\mathbf{4}$ was obtained by slow evaporation from the mixture $\mathrm{CH}_{2} \mathrm{Cl}_{2}-\mathrm{MeOH}$ (1:5) solution. Crystal data: $\mathrm{C}_{20} \mathrm{H}_{28} \mathrm{O}_{5} \cdot \mathrm{H}_{2} \mathrm{O}$, orthorhombic, $M_{\mathrm{r}}=366.44 \mathrm{~g} / \mathrm{mol} ; a=9.2869(19) \AA, b=9.3375(19) \AA, c=21.969(4) \AA$, $V=1905.1(7) \AA^{3}$, space group $P 2_{1} 2_{1} 2_{1}, Z=4, D_{\text {calcd }}=1.278 \mathrm{~g} / \mathrm{cm}^{3}$, $\lambda=0.71073 \AA, \mu($ Mo $\mathrm{K} \alpha)=0.093 \mathrm{~mm}^{-1}, F(000)=792, T=298(2) \mathrm{K} . \mathrm{A}$ total of 2170 reflections were collected in the range $1.85<\theta<26.00$, of which 2170 unique reflections with $I>2 \sigma(I)$ were used for the analysis. The data were solved using the direct method, and the structure was refined by full-matrix least-squares procedure on $F^{2}$ values. All non-hydrogen atoms were refined with anisotropic thermal parameters. The hydrogen atom positions were geometrically idealized and allowed to ride on their parent atoms. The final indices were $R 1=0.0327, w R 2=0.0861$ with goodnessof-fit $=1.032$.

\subsection{In vitro antimicrobial activity}

Bacterial strains were grown in LB (Luria-Bertani) broth medium for $24 \mathrm{~h}$ at $37{ }^{\circ} \mathrm{C}$. LB hard agar ( $17 \mathrm{~mL}, 1.5 \%$ agar) was poured into sterile Petri dishes $(9 \mathrm{~cm})$ and allowed to set. Molten LB soft agar $\left(2.7 \mathrm{~mL}, 0.7 \%\right.$ agar, $45^{\circ} \mathrm{C}$ ) was inoculated with $0.3 \mathrm{~mL}$ broth culture of the test organism and poured over the base hard agar plates forming a homogenous top layer. Sterile paper disc (Advantec, $8 \mathrm{~mm}$ ) were placed onto the top layer of the LB agar plates. Ten microliters of the tested compounds (1-10) were applied on to each filter paper discs. Ampicillin and same solvents were served as positive and negative control. All plates were incubated at $37^{\circ} \mathrm{C}$, $24 \mathrm{~h}$ for antibacterial activity evaluation. The antimicrobial activity of all isolated metabolites (1-10) was tested from 6.25, 12.5, 25, 50, $100,200,250,500$ up to $1000 \mu \mathrm{g} /$ disk on S. enteritidis (ATCC13076). The bacterial strain was obtained from the American Type Culture Collection. The antibiotic activity evaluation method was conducted based on previously reports. ${ }^{21}$

\subsection{In vitro anti-inflammatory assay}

The anti-inflammatory assay was modified from Ho et al. ${ }^{22}$ and Park et al. ${ }^{23}$ Murine RAW 264.7 macrophages were obtained from the American Type Culture Collection (ATCC, No. TIB-71). The cells were activated by incubation in medium containing Escherichia coli LPS $(0.01 \mu \mathrm{g} / \mathrm{mL}$; Sigma) for $16 \mathrm{~h}$ in the presence or absence of various compounds. Then, cells were washed with ice-cold PBS, lysed in ice-cold lysis buffer, and then centrifuged at 20,000g for $30 \mathrm{~min}$ at $4{ }^{\circ} \mathrm{C}$. The supernatant was decanted from the pellet and retained for Western blot analysis. Protein concentrations were determined by the DC protein assay kit (Bio-Rad) modified by the method of Lowry et al. ${ }^{24}$ Samples containing equal quantities of protein were subjected to SDS-polyacrylamide gel electrophoresis, and the separated proteins were electrophoretically transferred to polyvinylidene difluoride membranes (PVDF; Immobilon-P, Millipore, $0.45 \mu \mathrm{m}$ pore size). The resultant PVDF membranes were incubated with blocking solution and incubated for $180 \mathrm{~min}$ with antibody against inducible nitric oxide synthase (iNOS; 1:1000 dilution; Transduction Laboratories) and cyclooxygenase-2 (COX-2; 1:1000 dilution; Cayman Chemical) protein. The blots were detected using ECL detection reagents (Perkin-Elmer, Western Blot Chemiluminescence Reagent Plus) according to the manufacturer instructions.

\subsection{Inhibition of endonuclease activity assay}

The HCMV UL76 encodes an endonuclease ${ }^{25}$ was purified from E. coli BL21-codon DE3-RIL strain, which was transformed with calmodulin-tagged UL76 plasmid pCBP-UL76. The double-stranded supercoiled DNA $\varphi$ X174 was purified by $\mathrm{CsCl}$ gradient and used as substrate. ${ }^{26}$ Tested compounds were series diluted and incubated with $1 \mu \mathrm{g}$ DNA substrate, reaction buffer, and UL76 endonuclease at $37^{\circ} \mathrm{C}$ for $1 \mathrm{~h}$. After cleavage reaction, DNA was resolved in $1 \%$ agarose gel. Concentrations of tested compounds that exert $50 \%$ of inhibition of cleaved substrate $\left(\mathrm{IC}_{50}\right)$ were recorded.

\section{Acknowledgements}

This work was supported by grants from the National Science Council (NSC96-2320-B-110-003-MY3) and Ministry of Education (96C031703) of the Republic of China awarded to C.-Y. D.

\section{References and notes}

1. Blunt, J. W.; Copp, B. R.; Hu, W.-P.; Munro, M. H. G.; Northcote, P. T.; Prinsep, M. R. Nat. Prod. Rep. 2008, 25, 35-94 and literature cited in previous reviews.

2. Higuchi, R.; Miyamoto, T.; Yamada, K.; Komori, T. Toxicon 1998, 36, 1703-1705.

3. Matthee, G. F.; Konig, G. M.; Wright, A. D. J. Nat. Prod. 1998, 61, 237-240.

4. Wang, S.-K.; Duh, C.-Y.; Wu, Y.-C.; Wang, Y.; Cheng, M.-C.; Soong, K.; Fang, L.-S. J. Nat. Prod. 1992, 55, 1430-1435.

5. Coval, S. J.; Patton, R. W.; Petrin, J. M.; James, L.; Rothofsky, M. L.; Lin, S. L.; Patel, M.; Reed, J. K.; McPhil, A. T.; Bishop, W. R. Bioorg. Med. Chem. Lett. 1996, 6, 909-912.

6. Duh, C.-Y.; Wang, S.-K.; Huang, B.-T.; Dai, C.-F. J. Nat. Prod. 2000, 63, 884-885.

7. Yamada, K.; Ryu, K.; Miyamoto, T.; Higuchi, R. J. Nat. Prod. 1997, 60, 798-801.

8. Subrahmanyam, C.; Rao, C. V.; Anjaneyulu, V.; Satyanarayana, P.; Rao, P. V. S. Tetrahedron 1992, 48, 3111-3120.

9. Uchio, Y.; Eguchi, S.; Kuramoto, J.; Nakayama, M.; Hase, T. Tetrahedron Lett. 1985 26, 4487-4490.

10. Tursch, B.; Braekman, J. C.; Daloze, D.; Herin, M.; Karlsson, R. Tetrahedron Lett 1974, 43, 3769-3772.

11. Kashman, Y.; Groweiss, A. Tetrahedron Lett. 1977, 13, 1159-1160.

12. Kinamoni, Z.; Groweiss, A.; Carmely, S.; Kashman, Y. Tetrahedron 1983, 39, $1643-1648$.

13. Kashman, Y.; Carmely, S.; Groweiss, A. J. Org. Chem. 1981, 46, 3592-3596.

14. Rashid, M. A.; Gustafson, K. R.; Boyd, M. R. J. Nat. Prod. 2000, 63, 531-533.

15. Bowden, B. F.; Coll, J. C.; Tapiolas, D. M. Aust. J. Chem. 1983, 36, 2289-2295.

16. Bowden, B. F.; Coll, J. C.; Decosta, M. S. L.; Desilva, E. D.; Mackay, M. F.; Mahendran, M.; Willis, R. H. Aust. J. Chem. 1984, 34, 545-552.

17. Li, G.; Zhang, Y.; Deng, Z.; van Ofwegen, L.; Proksch, P.; Lin, W. J. Nat. Prod. 2005 $68,649-652$.

18. Ohtani, I.; Kusumi, T.; Kashman, Y.; Kakisawa, H. J. Am. Chem. Soc. 1991, 113, 4092-4096.

19. Djeddi, S.; Karioti, A.; Sokovic, M.; Stojkovic, D.; Seridi, R.; Skaltsa, H. J. Nat. Prod. 2007, 70, 1796-1799.

20. Crystallographic data for $\mathbf{4}$ have been deposited with the Cambridge Crystallographic Data Centre (deposition number CCDC 689497). Copies of the data can be obtained, free of charge, on application to the Director, CCDC, 12 Union Road, Cambridge CB21EZ, UK (fax: +44 1223336033 or e-mail: deposit@ccdc. cam.ac.uk).

21. (a) Hou, L.; Shi, Y.; Zhai, P.; Le, G. J. Ethnopharmacol. 2007, 111, 227-231; (b) Arias, M. E.; Gomez, J. D.; Cudmani, N. M.; Vattuone, M. A.; Isla, M. I. Life Sci. 2004, 75, 191-202.

22. Ho, F. M.; Lai, C. C.; Huang, L. J.; Kuo, T. C.; Chao, C. M.; Lin, W. W. Br. J. Pharmacol. 2004, 141, 1037-1047.

23. Park, E. K.; Shin, Y. W.; Lee, H. U.; Kim, S. S.; Lee, Y. C.; Lee, B. Y.; Kim, D. H. Biol Pharm. Bull. 2005, 28, 652-656.

24. Lowry, D. H.; Rosebrough, N. J.; Farr, A. L.; Randall, R. J. J. Biol. Chem. 1951, 193 265-275.

25. Knizewski, L.; Kinch, L.; Grishin, N. V.; Rychlewski, L.; Ginalski, K. J. Virol. 2006 $80,2575-2577$

26. Tachiwana, H.; Shimura, M.; Nakai-Murakami, C.; Tokunaga, K.; Takizawa, Y.; Sata, T.; Kurumizaka, H.; Ishizaka, Y. Cancer Res. 2006, 66, 627-631. 